\title{
Embryonic Stem Cells: An Exciting Field for Basic Research and Tissue Engineering, but also an Ethical Dilemma?
}

\author{
H.-W. Denker \\ Institut für Anatomie, Universitätsklinikum Essen, Germany
}

Key Words

Embryonic stem cells · Ethics

Recent reports describing that, not unexpectedly, human embryonic stem (ES) cells have become available [Shamblott et al., 1998; Thomson et al., 1998] suddenly put ES cells in the centre of public interest. Mouse ES cells have been known as a fascinating object of biological research for many years, and in particular they have proven useful as an experimental tool for basic studies on gene function. Their potential use as model systems for studies on basic aspects of differentiation processes was in the past exploited by only a limited, but steadily increasing, number of researchers. Since last year interest in this field seems to have experienced a quantum leap, in particular due to the fact that the primate, and especially human, ES cells now available may show considerable promise for broad applications in tissue engineering and transplantation. Indeed, they could be an ideal source of material for transplantation purposes in the human. We will of course never have enough donated human cells and organs to

\begin{tabular}{ll}
\hline KARGER & ( 1999 S. Karger AG, Basel \\
Fax +4161306 12 34 & Accessible online at: \\
$\begin{array}{l}\text { E-Mail karger@karger.ch } \\
\text { www.karger.com }\end{array}$ & $\begin{array}{l}\text { www.karger.com/journals/cto } \\
\text { wwo5/99/1654-0246\$17.50/0 }\end{array}$
\end{tabular}

meet all transplantation needs, in spite of all efforts that are being made. Xenotransplantation poses immunologic and animal protection problems. ES cells are attractive because they can proliferate and then be influenced by various cytokines to differentiate into certain directions, e.g. into the direction of haematopoietic stem cells that are of utmost interest in transplantation medicine [for animal experiments see e.g. Forrester et al., 1991; Palacios et al., 1995]. Studies along those lines are now being continued with human ES cells. ES cells are, on the other hand, also of considerable interest to embryologists and developmental biologists because they offer opportunities previously unavailable for performing studies on differentiation and pattern formation in mammals including (nonhuman) primates. It seems that the great practical use that derivatives of ES cell lines may find in transplantation medicine will increase the pressure to put much money and effort into such basic research on the regulation of differentiation in these systems.

I am very happy, therefore, that Anna Wobus and Kenneth Boheler have accepted to compile and edit this timely special issue of Cells Tissues Organs. I am sure it will be welcomed by the scientific community as a very impor-

\footnotetext{
Prof. Dr. med. Dr. rer. nat. H.-W. Denker

Institut für Anatomie, Universitätsklinikum Essen

Hufelandstrasse 55

D-45122 Essen (Germany)

Tel. +49 201723 4380/1, Fax +49 201723 5916, E-Mail denker@uni-essen.de
} 
tant actual source of information and will contribute to stimulating further discussions and further research in this field.

In all our excitement about ES cells we must, however, not overlook that, like many other technical achievements, these cells may also have a Janus-faced character. In particular, human ES cells confront us with a dilemma: as detailed below, primate ES cells may have the potential to form in vitro embryo-like structures and perhaps even complete embryos, which could raise grave ethical concerns. The question arises whether this could prohibit the use of these cells.

Let me make clear why I feel this latter, problematical aspect deserves our attention and why I think it asks for clarification by specifically designed experimental investigation. Non-human primate ES cell lines have been produced in the rhesus monkey and the marmoset (Callithrix jacchus) [Thomson et al., 1995, 1996]. Particularly remarkable are features of differentiation reported for the marmoset cell line. When propagated on a feeder cell layer as usual for ES cell culture, the cells can be maintained in an undifferentiated state. However, when these cells are allowed to differentiate by simply letting them grow at high density they develop embryo-like structures in vitro. These appear to be much more embryo-like than the 'embryoid bodies' known for a long time from work on mouse ES and teratocarcinoma cell lines (see below). Thomson et al. [1996] have published a picture (fig. 5) of such a spontaneously developed early embryo-like structure that appears to be identical with a normal primate embryo as found in vivo. It shows a well-formed embryonic shield, with amnion and an amniotic cavity, as well as a yolk sac. An early human embryo would look practically the same. Evidence for the differentiation of trophoblast, the cell type that normally forms the fetal part of the placenta, was also found in the marmoset ES cell line so that apparently every cell type was produced here in vitro. Even more importantly, a primitive streaklike structure was also formed in the epiblast in vitro. The primitive streak is one of the first signs of the main (craniocaudal) body axis and, at the same time, is the structural equivalent for the formation of two new germ layers, the mesoderm and the definitive endoderm. The formation of a normal-looking primitive streak in these embryo-like structures in vitro shows on one hand that they may indeed have to be addressed as complete embryos. On the other hand, formation of the primitive streak is thought to mark the onset of individuality, since monocygotic twinning is not possible after the primitive streak stage has been reached. Therefore, the primitive streak has been of utmost importance in all discussions about cloning, abortion and experimentation with human embryos. Development of the embryo-like structures (or embryos) in the monkey cell lines has not been followed further in vitro, as far as can be seen in the scientific literature, but taking these published data into account there can be no doubt that development could have proceeded to even more advanced stages, and there seems to be a high probability that well-formed embryos (rather than teratomas, see below) can grow in vitro. Given the high proliferative capacity of ES cells, this could then result in large numbers of identical, cloned embryos.

This is the only report I am aware of which claims that such a high degree of order can develop spontaneously in an in vitro culture of ES cells, but the same authors point out that this was not an isolated phenomenon [Thomson et al., 1996; Thomson and Marshall, 1998]. The formation of such a high degree of structural order in vitro is not known from mouse ES cells, although differentiation of virtually any cell type can be obtained and can already be manipulated to impressive degrees (as discussed in various contributions to this special issue of Cells Tissues Organs). Even if mouse 'embryoid bodies' are generated in vitro, a higher structural order is typically not obtained, as known from older literature [Sherman and Solter, 1975; Robertson, 1987]. At the organ level, an impressive degree of order has been observed after transplantation of primate ES cells ectopically into SCID mice, e.g. gut-like structures with not only a rather typical epithelium and villi, but even a rather typical stratification of the various layers of the gut wall including a lamina propria and various layers of musculature [Thomson and Marshall, 1998, fig. 9]. This is in line with many observations on spontaneously developing teratomas as well as on experimental teratomas in mice that have been well known for a long time [Sherman and Solter, 1975; Robertson, 1987]. What is not seen in spontaneously arising teratomas/teratocarcinomas or in teratomas produced after transplantation of embryos to ectopic sites is the formation of a harmonious whole embryo with intact main body axes. This has been seen, however, in a unique experiment with mouse ES cells transplanted into a temporary host embryo (which itself degenerated later because it consisted of lethal cells) [Nagy et al., 1993]. Until recently most people assumed that instructions from a host embryo are indeed essential here. The more remarkable appears to be the report by Thomson et al. [1996] that apparently a complete and well-shaped embryo with astonishingly welldeveloped extraembryonic membranes including an embryonic disc with primitive streak is formed in vitro by the marmoset ES cells. This sheds a special light on the well- 
documented observation that the environment into which totipotent early embryonic cells are brought greatly influences in particular axis formation and thus the formation of the general body plan. It must be remembered that even complete normal mouse embryos show disorganized differentiation and formation of teratomas when transplanted to ectopic sites, e.g. to the kidney [Sherman and Solter, 1975; Robertson, 1987].

In this context, we have to ask anew the question: what is so special about an egg or an early blastomere, and what do these cells provide specifically for the formation of a harmonious whole embryo? Are those 'fields of factors' or cytoplasmic determinants of the egg [if they exist in the mammalian system, as discussed recently again on the basis of new findings, Antczak and van Blerkom, 1997; Beddington and Robertson, 1999; Edwards and Beard, 1997; Gardner, 1997; Zernicka-Goetz, 1998; cf. Denker, 1976] dispensable in a confluent in vitro culture of primate ES cells? How is axis formation brought about and regulated under these conditions? These are very important questions that urgently need to be studied experimentally, and this can now be done with primate ES cells. I personally feel that it should, however, never be attempted with human ES cells, and the scientific desire to study the behaviour of human ES cells must be satisfied with analogies or homologies gleaned from comparative studies on non-human primate species.

Mammalian and human embryos are of course always thought to be necessarily derived from eggs. All discussions about the legal status of the embryo and about moral implications of embryo-related technology have this type of embryo in mind. Eggs are a rare type of cells, since only few egg cells are produced during the reproductive years of a woman. Even when follicle growth and egg cell production in the ovary are stimulated hormonally the number of eggs produced remains limited. (It may be added that our attitude seems to be different with respect to gametes that are normally produced in abundant quantity, i.e. sperm.) What also appears relevant to our traditional thinking and arguing is the limited capacity of the female genital tract which allows growth of and giving birth to only one or a few embryos at a time. I feel that the public attention that has been paid and is being paid for example to experiments on the cloning of farm animals like the sheep Dolly [Wilmut et al., 1997] using technologies based on egg-derived embryos must appear exaggerated in comparison with the potential that lies in ES cells, since all egg-based procedures still meet considerable technical problems, need a lot of time and effort and can therefore be done only on a very limited scale due to the limited availability of eggs. The situation would obviously be different if the same type of thing (i.e. cloning) could be done with ES cells alone that can be produced in unlimited quantity.

A major organizing element in an egg or embryo may be positional information, structuring cues, asymmetric distribution of molecules, and the way how these direct the formation of axes (dorsovertral, anterior-posterior, proximodistal). That this can theoretically be achieved by very simple physicochemical mechanisms was shown in computer models [Meinhardt, 1989, 1996]. Modern work about axis formation in the early insect embryo [St Johnston and Nüsslein-Volhard, 1992; Nilson and Schüpbach, 1998] identifies an increasing number of genes and gene products that appear to be the players in this game. The question to what extent these genes may be related to those that are at work in vertebrates including mammals and man, and how they might be related to any polar organization of the mammalian egg [see Antczak and van Blerkom, 1997; Gardner, 1997; Zernicka-Goetz, 1998] is naturally of great interest. Will ES cells be helpful here by providing an easily accessible experimental system? The remarkable ability of primate ES cells to form embryolike structures (or even embryos) in vitro, mentioned above, may suggest this.

The specific feature of the egg can be thought to be that it provides very simple asymmetries and that it secures in this way a degree of structural order for the orthotopic formation of single body axes (in contrast to multiple or branched axes) so that the subsequent patterning of all tissues in the emerging embryo will lead to the formation of a harmonious, functional whole. It is a peculiar feature of eggs and totipotent blastomeres, on the other hand, that they can regulate defects and restitute such a harmonious whole. It is possibly due to this flexibility and to these mechanisms that, as we have seen in the example of ES cells in vitro, order can also develop spontaneously in a cell culture, in this case independent of an egg-derived prepattern. Here stochastic molecular events (of the type that can perhaps be best described by the chaos theory) may generate a first simple asymmetry. If eggs, early embryonic cells (blastomeres) and ES cells all have the same totipotency an exciting topic for ongoing and future research is of course whether they all make use of the same hierarchically dependent (and vectorial) processes of differentiation, cell movements and cell-to-cell interactions for the development of complex order.

An old aphorism, based on one of the founders of experimental embryology, Carl Ernst von Baer, sometimes mistaken as expressing preformistic views, states: 
'Entwicklung ist Umbildung von einer Gestalt zur anderen' [as formulated by Seidel, 1960]. Will it have to be reformulated or re-interpreted in the light of the remarkable pattern-forming abilities of the ES cells? And what does all this mean for the ethical aspects and legal status of human ES cells?

\section{Acknowledgement}

I wish to thank PD Dr. med. Th. Heinemann, PD Dr. med. Ch. Viebahn and my wife, Dr. med. U. Denker for helpful comments.

\section{References}

Antczak, M., J. van Blerkom (1997) Oocyte influences on early development: The regulatory proteins leptin and STAT3 are polarized in mouse and human oocytes and differentially distributed within the cells of the preimplantation stage embryo. Mol Hum Reprod 3: 10671086.

Beddington, R.S.P., E.J. Robertson (1999) Axis development and early asymmetry in mammals. Cell 96: 195-209.

Denker, H.-W. (1976) Formation of the blastocyst: determination of trophoblast and embryonic knot; in Gropp, A., K. Benirschke (eds): Developmental Biology and Pathology. Current Topics in Pathology. Berlin, Springer, vol 62, pp 59-76.

Edwards, R.G., H.K. Beard (1997) Oocyte polarity and cell determination in early mammalian embryos. Mol Hum Reprod 3: 863-905.

Forrester, L.M., A. Bernstein, J. Rossant, A. Nagy (1991) Long-term reconstitution of the mouse haematopoietic system by embryonic stem cellderived fetal liver. Proc Natl Acad Sci USA 88: 7514-7517.

Gardner, R. (1997) The early blastocyst is bilaterally symmetrical and its axis of symmetry is aligned with the animal-vegetal axis of the zygote in the mouse. Development 124: 289301.

Meinhardt, H. (1989) Models for positional signalling with aplication to the dorsoventral patterning of insects and segregation into different cell types. Development 107(suppl): 169-180.
Meinhardt, H. (1996) Models of biological pattern formation: Common mechanism in plant and animal development. Int J Dev Biol 40: 123 134

Nagy, A., J. Rossant, R. Nagy, W. Abramow-Newerly, J.C. Roder (1993) Derivation of completely cell culture-derived mice from early-passage embryonic stem cells. Proc Natl Acad Sci USA 90: 8424-8428.

Nilson, L.A., T. Schüpbach (1998) Localized requirements for windbeutel and pipe reveal a dorsoventral prepattern within the follicular epithelium of the Drosophila ovary. Cell 93 . 253-262.

Palacios, R., E. Golunski, J. Samaridis (1995) In vitro generation of hematopoietic stem cells from an embryonic stem cell line. Proc Natl Acad Sci USA 92: 7530-7534.

Robertson E.J. (1987) Teratocarcinomas and Embryonic Stem Cells: A Practical Approach. Oxford, IRL Press.

Seidel, F. (1960) Körpergrundgestalt und Keimstruktur. Eine Erörterung über die Grundlagen der vergleichenden und experimentellen Embryologie und deren Gültigkeit bei phylogenetischen Überlegungen. Zool Anz 164: 245-305.

Shamblott, M.J., J. Axelman, S. Wang, E.M. Bugg, J.W. Littlefield, P.J. Donovan, P.D. Blumenthal, G.R. Huggins, J.D. Gearhart (1998) Derivation of pluripotent stem cells from cultured human primordial germ cells. Proc Natl Acad Sci USA 95: 13726-13731.
Sherman, M.I., D. Solter (1975) Teratomas and Differentiation. New York, Academic Press.

St Johnston, D., C. Nüsslein-Volhard (1992) The origin of pattern and polarity in the Drosophila embryo. Cell 68: 201-219.

Thomson, J.A., J. Itskovitz-Eldor, S.S. Shapiro, M.A. Waknitz, J.J. Swiergiel, V.S. Marshall, J.M. Jones (1998) Embryonic stem cell lines derived from human blastocysts. Science 282: 1145-1147.

Thomson, J.A., J. Kalishman, T.G. Golos, M. Durning, C.P. Harris, R.A. Becker, J.P. Hearn (1995) Isolation of a primate embryonic stem cell line. Proc Natl Acad Sci USA 92: 78447848.

Thomson, J.A., J. Kalishman, T.G. Golos, M. Durning, C.P. Harris, J.P. Hearn (1996) Pluripotent cell lines derived from common marmoset (Callithrix jacchus) blastocysts. Biol Reprod 55: 254-259.

Thomson, J.A., V.S. Marshall (1998) Primate embryonic stem cells. Curr Top Dev Biol 38: 133165.

Wilmut, I., A.E. Schnieke, J. McWhir, A.J. Kind, K.H.S. Campbell (1997) Viable offspring derived from fetal and adult mammalian cells. Nature 385: 810-813.

Zernicka-Goetz, M. (1998) Fertile offspring derived from mammalian eggs lacking either animal or vegetal poles. Development 125: 48034808 . 